\title{
Acute crack cocaine exposure induces genetic damage in multiple organs of rats
}

\author{
Eduardo Gregolin Moretti ${ }^{1}$. Veronica Quispe Yujra ${ }^{2} \cdot$ Samuel Rangel Claudio ${ }^{1}$. \\ Marcelo Jose Dias Silva ${ }^{3}$ - Wagner Vilegas ${ }^{3}$. Camilo Dias Seabra Pereira ${ }^{4}$. \\ Flavia de Oliveira ${ }^{1} \cdot$ Daniel Araki Ribeiro $^{1,2}$
}

Received: 24 April 2015 / Accepted: 20 January 2016 /Published online: 29 January 2016

(C) Springer-Verlag Berlin Heidelberg 2016

\begin{abstract}
Crack cocaine is a very toxic product derived from cocaine. The aim of this study was to evaluate genetic damage in multiple organs of rats following acute exposure to crack cocaine. A total of 20 Wistar rats were distributed into four groups ( $n=5$ ), as follows: $0,4.5,9$, and $18 \mathrm{mg} / \mathrm{kg}$ body weight (b.w.) of crack cocaine administered by intraperitoneal route (i.p.). All animals were killed $24 \mathrm{~h}$ after intraperitoneal (i.p.) injection. The results showed that crack cocaine increased the number of micronucleated cells in bone marrow cells exposed to $18 \mathrm{mg} / \mathrm{kg}$ crack cocaine $(p<0.05)$. Peripheral blood and liver cells presented genetic damage as depicted by single cell gel (comet) assay at 9 and $18 \mathrm{mg} / \mathrm{kg}$ doses $(p<0.05)$. Immunohistochemistry data revealed significant increase in 8-hydroxy-20-deoxyguanosine (8-OHdG) immunoexpression in hepatocytes of animals exposed to crack cocaine at 9 and $18 \mathrm{mg} / \mathrm{kg}(p<0.05)$ when compared with negative controls. Taken together, our results demonstrate that crack cocaine is able to induce genomic damage in multiple organs of Wistar rats.
\end{abstract}

Responsible editor: Markus Hecker

Daniel Araki Ribeiro

daribeiro@unifesp.br; ak92@hotmail.com

1 Departamento de Biociências, Universidade Federal de São Paulo-UNIFESP, Av. Ana Costa 95, Zip Code 11060-001 Santos, SP, Brazil

2 Department of Pathology, Federal University of Sao Paulo, UNIFESP, Santos, SP, Brazil

3 Sao Paulo State University, UNESP, Campus Litoral Paulista, Sao Vicente, SP, Brazil

4 Department of Sea Sciences, Federal University of Sao Paulo, UNIFESP, Santos, SP, Brazil
Keywords Crack cocaine $\cdot$ Genomic instability $\cdot$ DNA damage $\cdot$ Rat

\section{Introduction}

Crack cocaine use has been introduced in Brazil in the late 1980s or early 1990s, and its use has increased dramatically in the last decades for all socioeconomic groups (Oliveira and Nappo 2008; Moura et al. 2014). Unofficial data have revealed that Brazil has approximately three million regular users of cocaine, accounting for $20 \%$ of its consumption worldwide. Today, Brazil is also the world's largest market for crack cocaine (Laranjeira et al. 2012). Crack cocaine users present a worse prognosis when compared with other illicit drugs because it causes more severe dependence, involvement with criminality, risky sexual behavior, and more social impairments (Vaughn et al. 2010).

Substance abuse disorders include both intrinsic and extrinsic factors in their etiological models (Kendler et al. 2007). It has been established that crack cocaine can cause hypertension, tachycardia, muscle twitching, and convulsions as far as coma and death (Riezzo et al. 2012). At the molecular level, crack cocaine deregulated some systemic cytokines such as brain-derived neurotrophic factor (BDNF), interleukin (IL)$1 \beta$, IL-10, pro-inflammatory TNF- $\alpha$, as well as induced lipid peroxidation (Narvaez et al. 2013). It seems that oxidative stress plays an important role in the pathogenesis of psychiatric disorders, including drug addiction (Narvaez et al. 2013). For example, short-term effects of cocaine lead to increased dopamine levels in the synaptic cleft in the brain reward system, increased production of reactive oxygen species (ROS), and cellular damage in various tissues (Hermida-Ameijeiras et al. 2004; Zaparte et al. 2015). This can lead to cellular response, such as oxidative DNA damage, and several 
enzyme impairments producing detrimental effects at both cellular and systemic levels (Halliwell 2006). Herein, it would be interesting to know if, and to what extent, crack cocaine exposure is able to induce genetic instability in two or more organs as a result of oxidative stress, particularly because there are no previous reports using experimental models.

Following the uptake and metabolism of the crack cocaine, type and number of lesions may be different among tissues in the living organisms. In this regard, it is important to analyze different organs in order to detect what cellular types are more sensitive to the damage after crack cocaine exposure (Minicucci et al. 2008). Genotoxicity assays have been widely used for evaluating chemical mutagens and carcinogens. The single cell gel (comet) and micronucleus assays are suitable methodologies for this purpose. The comet assay is a very sensitive method able to detect genetic damage in any eukaryotic cell (Tice et al. 2000). It is a sensitive, fast, low-cost technique widely used that is able to detect several types of DNA lesions including single and double strand breaks, adducts, and incomplete repair sites (Tice et al. 2000). Micronuclei (MN) arise from acentric fragments or whole chromosomes, which are not included in the main nuclei of the daughter cells. The formation of MN can be induced by substances that cause chromosome breakage (clastogens) as well as by agents that affect the spindle apparatus (aneugens) (Beliën et al. 1995).

The aim of this study was to evaluate genomic damage in multiple organs of rats following acute exposure to crack cocaine.

\section{Materials and methods}

\section{Animals and experimental design}

The study was approved by the Animal Ethics Committee of the Federal University of Sao Paulo, UNIFESP, SP, Brazil (protocol no. 5816200114).

A total of 20 Wistar rats weighing $250 \mathrm{~g}$ on average, and 8 weeks of age were distributed into four groups $(n=5)$, as follows: $0,4.5,9$, and $18 \mathrm{mg} / \mathrm{kg}$ body weight (b.w.) of crack cocaine administered by intraperitoneal route (i.p.). The dose levels used correspond, respectively, to $6.25,12.5$, and $25 \%$ of the cocaine lethal dose to $50 \%$ (LD50) in rodents (Salvadori et al. 1998). Crack cocaine was diluted in dimetilsulphoxide (DMSO) because it is not a hydro-soluble substance. The choice of using DMSO as vehicle was based on the fact that it is a carrier solvent and also a chelating agent. To standardize the amount of i.p. injection, the final volume used was $1 \mathrm{~mL}$ for all animals. All animals were euthanized $24 \mathrm{~h}$ after i.p. injection. The drug was donated as a courtesy by the Criminal Department of Limeira City, Sao Paulo State, Brazil for research purposes.

\section{Chemical analysis}

\section{Sample preparation}

For this analysis, the presence of cocaine as the main component was evaluated in the crack cocaine sample used in this setting. Ten milligrams of crack cocaine was dissolved in $10 \mathrm{~mL}$ of methanol (Merck, Darmstadt, Germany). After centrifugation at $3000 \times g$, the upper layer was transferred to a glass and analyzed by thin-layer chromatography (TLC) and electrospray ionization multistage mass spectrometry (ESI$\mathrm{MS}^{n}$ ) (Van Berkel et al. 2005). The supernatant was filtered through a nylon membrane disk at $22.25 \mathrm{~mm}$ diameter and $0.22 \mu \mathrm{m}$ pore size (Flow Supply, Cotia, SP, Brazil).

\section{TLC procedure}

Pre-coated plates (silica gel 60 GF 254, Merck, 6100 Darmstadt, Germany) were used in all cases. The plates were dried for $30 \mathrm{~min}$ at $80^{\circ} \mathrm{C}$ and then stored in a desiccator. The sample solution $(3 \mu \mathrm{L})$ was applied to silica gel plates. These plates were then developed in a horizontal chamber (Camag, Switzerland). The developing distance was $8 \mathrm{~cm}$. Mobile phases were methanol, chloroform, and acetic acid (20:75:5 vol.\%) (Merck, Damstadt, Germany) (Sabino et al. 2011). After this, the plates were dried at $100{ }^{\circ} \mathrm{C}$ for $15 \mathrm{~min}$. Spots were detected and marked under ultraviolet (UV) radiation at $254 \mathrm{~nm}$.

\section{ESI-MS $^{n}$ analyis}

ESI-MS $^{n}$ data were collected in the positive ion mode with a Fleet LCQ Plus ion-trap instrument from Thermo Scientific. The capillary voltage was set at $-20 \mathrm{kV}$, the spray voltage at $-5 \mathrm{kV}$, and the tube lens offset at $100 \mathrm{~V}$, sheath gas (nitrogen) flow rate at 80 (arbitrary units), and auxiliary gas flow rate at 5 (arbitrary units). Data were acquired in MS1 and MS ${ }^{n}$ scanning modes. The diluted solution obtained by TLC procedure was then directly infused into the ESI source at a flow rate of $10 \mathrm{~mL} / \mathrm{min}$ via a microsyringe pump. The mass analyzer was set to scan along a $m / z$ range of 75-2000. ESI-MS/MS experiments were carried out by selection of a specific ion by Q1 and then submitting this to collision-induced dissociation with $\mathrm{Ar}$ in a collision chamber. The capillary temperature was $275{ }^{\circ} \mathrm{C}$. Xcalibur 2.1 software (Thermo Scientific) was used for data analysis. The degree of confidence for this method is $99 \%$.

\section{Micronucleus test}

After completing the exposure period, the micronucleus test was performed with bone marrow and liver tissues. The bone marrow micronucleus test was performed according 
to de Moura et al. (2014). For this purpose, femoral bones were collected and stored in sodium chloride $(0.9 \%)$. The proximal epiphyses of the bones were removed and $1 \mathrm{~mL}$ of fetal calf serum (FBS; Cultilab ${ }^{\mathrm{TM}}$, Campinas, São Paulo, Brazil) was injected into the medullar canal. A smear on glass slides was performed with the suspension formed by the bone marrow and fetal calf serum. After drying the slides, they were stained with Giemsa (Merck ${ }^{\mathrm{TM}}$, Darmstadt, Germany). For liver micronucleus test, paraffin sections $(3 \mu \mathrm{m})$ were stained by Feulgen and counterstained with Fast Green (Sigma Aldrich ${ }^{\mathrm{TM}}$, USA). A total of 1000 polychromatic erythrocytes or hepatocytes were analyzed per animal. Slides were scored blindly using a light microscope with a $\times 100$ oil immersion objective.

\section{Single cell gel (comet) assay}

The protocol used for peripheral blood, kidney, and liver cells followed the guidelines outlined by Tice et al. (2000). Peripheral blood was collected by cardiac puncture and liver, and kidney cells were obtained by liver tissue maceration with phosphate buffer solution (PBS). Cells were transferred to individual plastic tubes, containing $1 \mathrm{~mL}$ of cold $\mathrm{PBS}\left(\mathrm{Ca}^{+2}\right.$, $\mathrm{Mg}^{+2}$ free, $\mathrm{pH}$ 7.3), and centrifuged for $5 \mathrm{~min}, 1000 \mathrm{rpm}$, at room temperature. The supernatant was removed, and the cell suspensions $(\sim 10 \mu \mathrm{L})$ were in the comet assay. A volume of $10 \mu \mathrm{L}$ of cellular suspension was added to $120 \mu \mathrm{L}$ of $0.5 \%$ low-melting point agarose at $37^{\circ} \mathrm{C}$, layered onto a pre-coated slide with $1.5 \%$ regular agarose and covered with a coverslip. After brief agarose solidification in a refrigerator, the coverslip was removed and the slides immersed in lysis solution $(2.5 \mathrm{M}$ $\mathrm{NaCl}, 100$ mM EDTA, Merck ${ }^{\mathrm{TM}}$, Darmstadt, Germany; $10 \mathrm{mM}$ Tris-HCl buffer, $\mathrm{pH}$ 10, Sigma Aldrich ${ }^{\mathrm{TM}}$, St Louis, MO, EUA; 1 \% sodium sarcosinate, Sigma ${ }^{\mathrm{TM}}$, St Louis, MO, EUA; with $1 \%$ Triton X-100, Sigma ${ }^{\mathrm{TM}}$, St Louis, MO, USA; $10 \%$ dimethyl sulphoxide, Merck ${ }^{\mathrm{TM}}$ ) for about $1 \mathrm{~h}$. Afterwards, the slides were washed in ice-cold PBS $\left(\mathrm{Ca}^{+2}\right.$, $\mathrm{Mg}^{+2}$ free, $\mathrm{pH}$ 7.3) for $5 \mathrm{~min}$, left in electrophoresis buffer $\left(0.3 \mathrm{mM} \mathrm{NaOH}\right.$ and $1 \mathrm{mM}$ EDTA, Merck $\left.{ }^{\mathrm{TM}}, \mathrm{pH}>13\right)$ for DNA unwinding during $20 \mathrm{~min}$ and electrophoresed in the same buffer for $20 \mathrm{~min}$ at $25 \mathrm{~V}(0.86 \mathrm{~V} / \mathrm{cm})$ and $300 \mathrm{~mA}$. Following electrophoresis, slides were neutralized in $0.4 \mathrm{M}$ Tris-HCl ( $\mathrm{pH} 7.5$, Sigma Aldrich ${ }^{\mathrm{TM}}$ ), fixed in absolute ethanol, and stored at room temperature until analysis under a fluorescence microscope at $\times 400$ magnification. All steps were performed under reduced light.

A total of 50 randomly captured comets per animal (25 cells from each slide) were examined blindly by one expert observer at $\times 400$ magnification using a fluorescent microscope (Olympus ${ }^{\mathrm{TM}}$, Orangeburg, NY, USA). The microscope was connected through a black and white camera to an image analysis system (Comet Assay II, Perceptive Instruments ${ }^{\mathrm{TM}}$, Suffolk, Haverhill, UK) calibrated previously according to the manufacturer's instructions. To measure DNA damage, we used the tail moment defined as the product of the tail length and the fraction of DNA in the comet tail (Tice et al. 2000).

\section{Histopathologic analysis}

After fixation in $10 \%$ buffered formalin, liver and left kidney of each animal were gradually dehydrated in alcohol, cleared in xylene, and embedded in paraffin blocks. Tissues were cut into 3-4- $\mu \mathrm{m}$-thick sections and were stained with hematoxylin-eosin (H.E.) for histopathological evaluation. Changes of livers and kidneys were evaluated by two independent members. When discrepant results were obtained, a consensus is reached.

\section{8-OHdG immunohistochemistry}

Liver serial sections of $4 \mu \mathrm{m}$ were de-paraffinized in xylene and rehydrated in graded ethanol (99.5\%), then pretreated in a microwave with $10 \mathrm{mM}$ citric acid buffer (pH 6, 0.1 M citric acid, Synth' ${ }^{\mathrm{TM}}$, São Paulo, Brazil; $0.1 \mathrm{M}$ sodium citrate, Synth ${ }^{\mathrm{TM}}$, São Paulo, Brazil) for 3 cycles of $5 \mathrm{~min}$ each for antigen retrieval. Slides were preincubated with $0.3 \%$ hydrogen peroxide for inactivation of endogenous peroxidase and then blocked with $5 \%$ normal goat serum for $30 \mathrm{~min}$. The specimens were then incubated with anti-8-hydroxy-20-deoxyguanosine (8OHdG; Santa Cruz Biotechnologies Inc ${ }^{\mathrm{TM}}$, MO, USA) at 1:100 dilution, overnight, at $4{ }^{\circ} \mathrm{C}$. This was followed by two washes in PBS and further incubation with a biotinylated secondary antibody, diluted 1:100 in PBS for $1 \mathrm{~h}$. The sections were washed twice with PBS followed by the application of preformed avidin biotin complex (Vector Technologies ${ }^{\mathrm{TM}}$, USA) for $45 \mathrm{~min}$. The bound complexes were visualized by the application of a $0.05 \%$ solution of 3,3-diaminobenzidine $\left(\mathrm{Sigma}^{\mathrm{TM}}\right)$ and counterstained with hematoxylin $\left(\operatorname{Sigma}^{\mathrm{TM}}\right)$. Sections stained using immunohistochemistry were analyzed for the percentages of immunopositive cells in liver. A total of 1000 hepatocytes were evaluated in three to five fields at $\times 400$ magnification. These values were used as labeling indices.

\section{Statistical analysis}

All data were expressed as mean \pm standard deviation (SD). One-way analysis of variance was performed followed by Tukey's multiple comparisons test. Statistical analysis was performed using Graph Pad Prism ${ }^{\mathrm{TM}} 6.0$ program. $p<0.05$ was considered to be significant. 


\section{Results}

\section{Chemical analysis}

Screening of the drug showed spots with a $R f$ value very close to 0.15 in the solvent system methanol/chloroform/acetic acid (20:75:5 vol.\%). Similar results were observed for the analysis of the pattern of cocaine TLC $(\mathrm{Rf} \approx 0.15)$ in studies of Sabino et al. (2011).

The analysis of the sample of the drug by ESI-MS revealed spectra generated by ionization in positive mode with abundant peak mass/charge of 304.24 and collision energy range from 25 to $30 \%$ (Fig. 1a). The results showed fragmentation characteristics at $m / z 272,182$, and 150, respectively (Fig. 1b). These fragmentation patterns in the MS/MS experiments suggest the presence of cocaine in the sample as the main component.

\section{Micronucleus test}

Micronucleus test in bone marrow and liver data showed that crack cocaine was able to significantly stimulate micronuclei formation in bone narrow cells only at the highest dose used in this study. Rats exposed to 9 and $4.5 \mathrm{mg} / \mathrm{kg}$ did not have increased micronucleus formation in bone marrow cells $(p>0.05)$ when compared with the control group (Fig. 2).

In hepatocytes, crack cocaine exposure did not show significantly increased micronucleus formation at any of the doses used in this study when compared with the control group (Fig. 2).

\section{Comet assay}

Peripheral blood cells were evaluated for DNA damage. Blood cells exposed to crack cocaine at doses of 9 and $18 \mathrm{mg} / \mathrm{kg}$ had significantly increased genetic damage when compared with the control group $(p<0.05)$. The dose of $4.5 \mathrm{mg} / \mathrm{kg}$ was not able to induce genetic damage after acute exposure of crack cocaine since no statistically significant differences $(p>0.05)$ were noticed. When liver cells were analyzed, interesting results were found. Hepatocytes exposed to crack cocaine demonstrated genetic damage only at the highest dose used $(18 \mathrm{mg} / \mathrm{kg}, p<0.05)$. Liver cells exposed after $24 \mathrm{~h}$ to crack cocaine at 9 and $4.5 \mathrm{mg} / \mathrm{kg}$ did not show statistically significant differences $(p>0.05)$ when compared with the control group (Fig. 3).

Finally, kidney cells were also evaluated in this study. Crack cocaine did not induce genetic damage in kidney cells at any of the doses used in this study (Fig. 3). No statistically significant differences $(p>0.05)$ were detected among groups.

\section{Histopathological findings}

Microscopic analyses were conducted with livers and kidneys of animals exposed to crack cocaine. Control animals not exposed to crack cocaine showed normal cellular architecture characterized by distinct hepatic cells, uniform nuclei, sinusoidal spaces, and a preserved central vein (Fig. 4a). In animals exposed to crack cocaine, the same picture occurred, i.e., no remarkable differences were found at any doses used in this study (Fig. 4b-d.).

Regarding kidney, histopathological changes were not detected for any animals (control and experimental groups), and

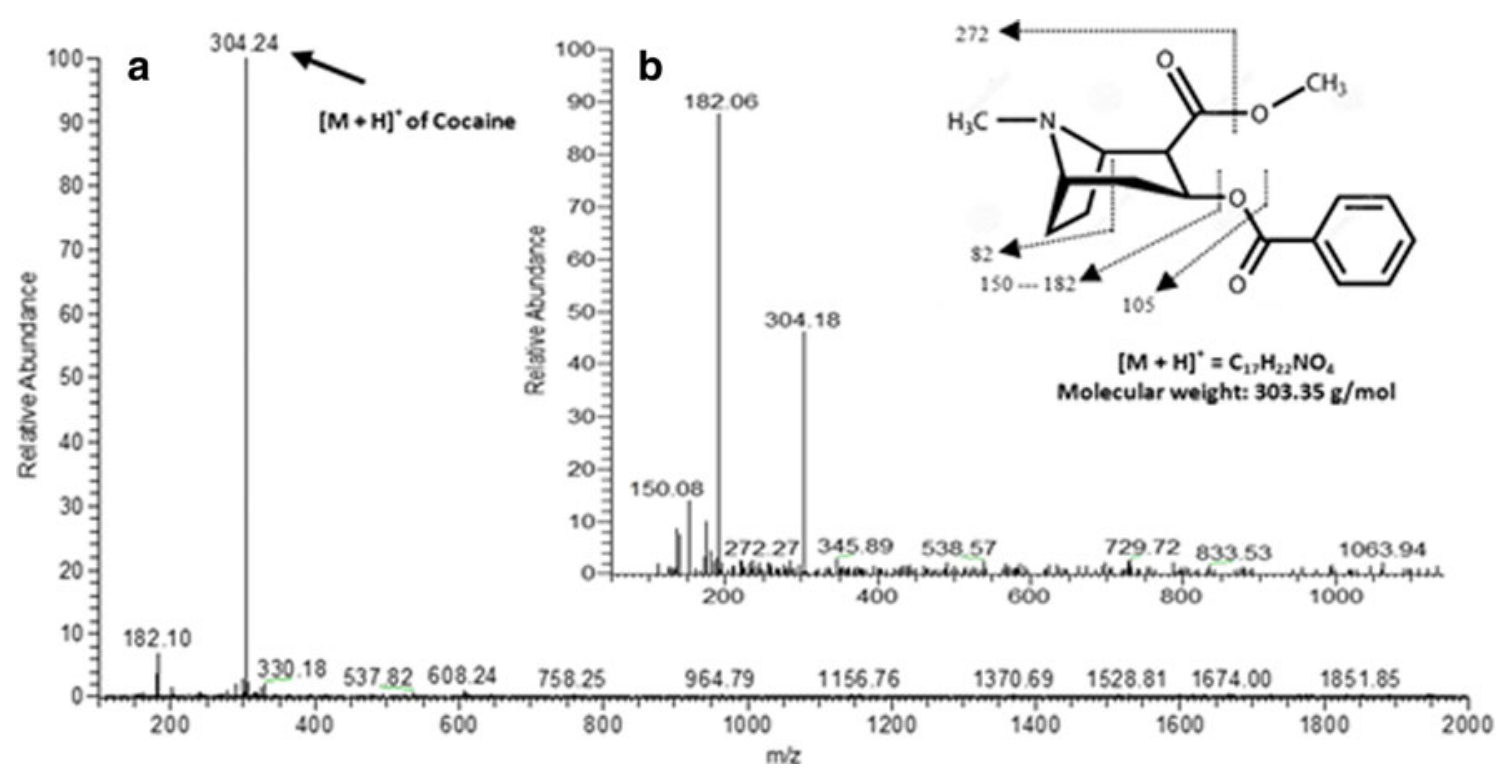

Fig. 1 Mass spectrum from first order, in full-scan mode positive way. Range of íons with $\mathrm{m} / \mathrm{z} 0-1851.85 \mathrm{Da}$. a Identification of cocaine $(\mathrm{m} / \mathrm{z} 304$, [M+ $\left.\mathrm{H}]^{+} \mathrm{C}_{17} \mathrm{H}_{22} \mathrm{NO}_{4}\right)$ in significant abundance; $\mathbf{b} \mathrm{MS}^{n}$ spectra of cocaine $\left(m / z 272,182\right.$, and $\left.150,[\mathrm{M}+\mathrm{H}]^{+}\right)$ 
Fig. 2 Mean $\pm \mathrm{SD}$ of micronucleated cells after acute crack cocaine exposure. $p<0.05$ when compared with control group

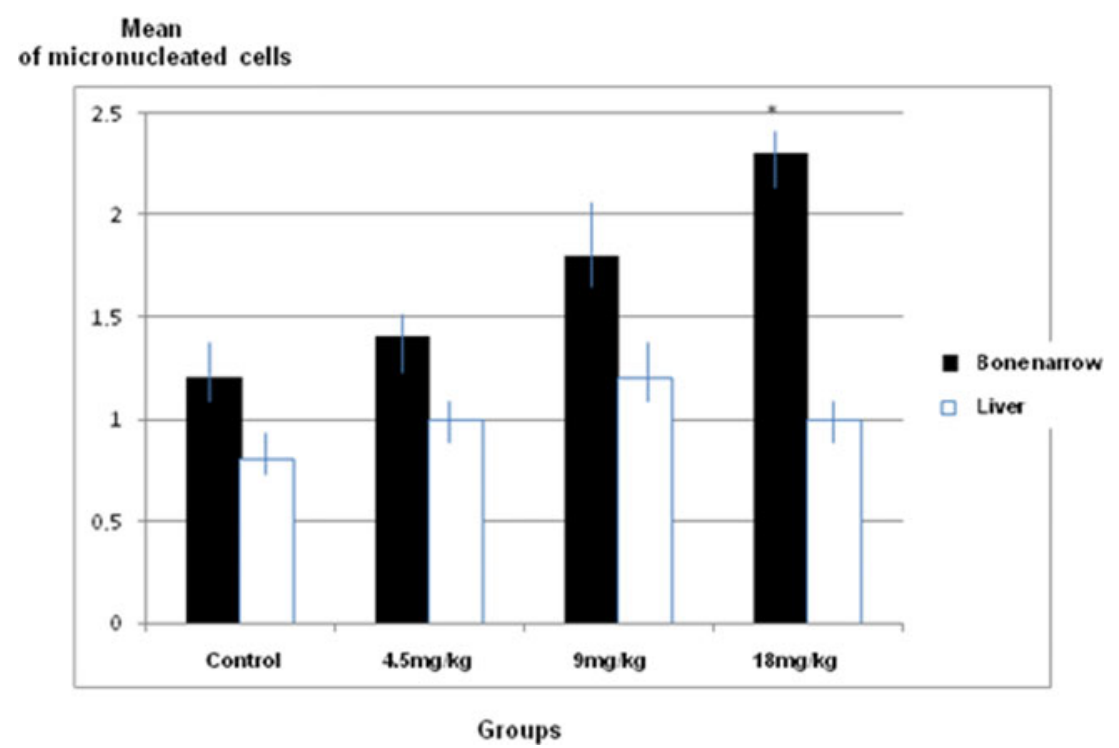

tissue morphology showed ordinary appearance. Glomerulli and proximal tubules of the cortical area presented a normal structure (Fig. 5).

\section{Immunohistochemistry}

Expression of 8-OHdG was characterized in the cytoplasm of liver cells by immunohistochemistry. Semi-quantitative data revealed a statistically significant increase in $8-\mathrm{OHdG}$ immunoexpression in the hepatocytes of animals exposed to crack cocaine at 9 and $18 \mathrm{mg} / \mathrm{kg}$ doses used in this study (Figs. 6 and 7,p<0.05) when compared with the control group. Animals exposed to crack cocaine at $4.5 \mathrm{mg} / \mathrm{kg}$ did not show statistically significant differences $(p>0.05)$ when compared with the control group. The immunoexpression in these groups was absent. Therefore, the analysis was considered negative for both groups.

\section{Discussion}

Toxicological effects of cocaine and their derivates on the central nervous system have already been described in murine and human studies (Alvarenga et al. 2010; Salzwedel et al. 2015). However, to the best of our knowledge, no data on the genotoxicity of crack cocaine have been reported previously. For this reason, the study was designed to assess toxicity of this drug on other organ systems using concentrations based on LD50 of cocaine. It is important to determine the doseresponse relationships for crack cocaine to characterize the potential risk resulting from acute exposure $(24 \mathrm{~h}$ after
Fig. 3 DNA damage (tail moment) in animals exposed to crack cocaine after 24 h. ${ }^{*} p<0.05$ when compared with control group

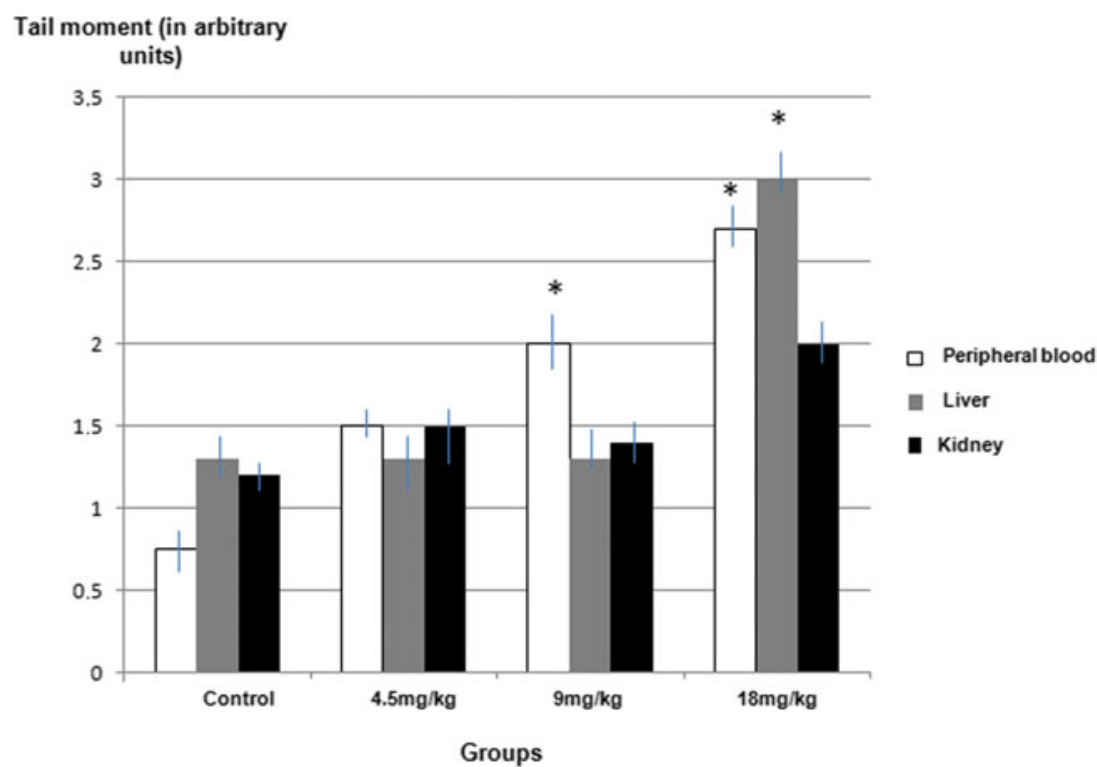


Fig. 4 Photomicrographies from liver of rats exposed to crack cocaine. a Control; b $4.5 \mathrm{mg} / \mathrm{kg}$; 9; d $18 \mathrm{mg} / \mathrm{kg} ; \times 40$ magnification (H.E. stain)

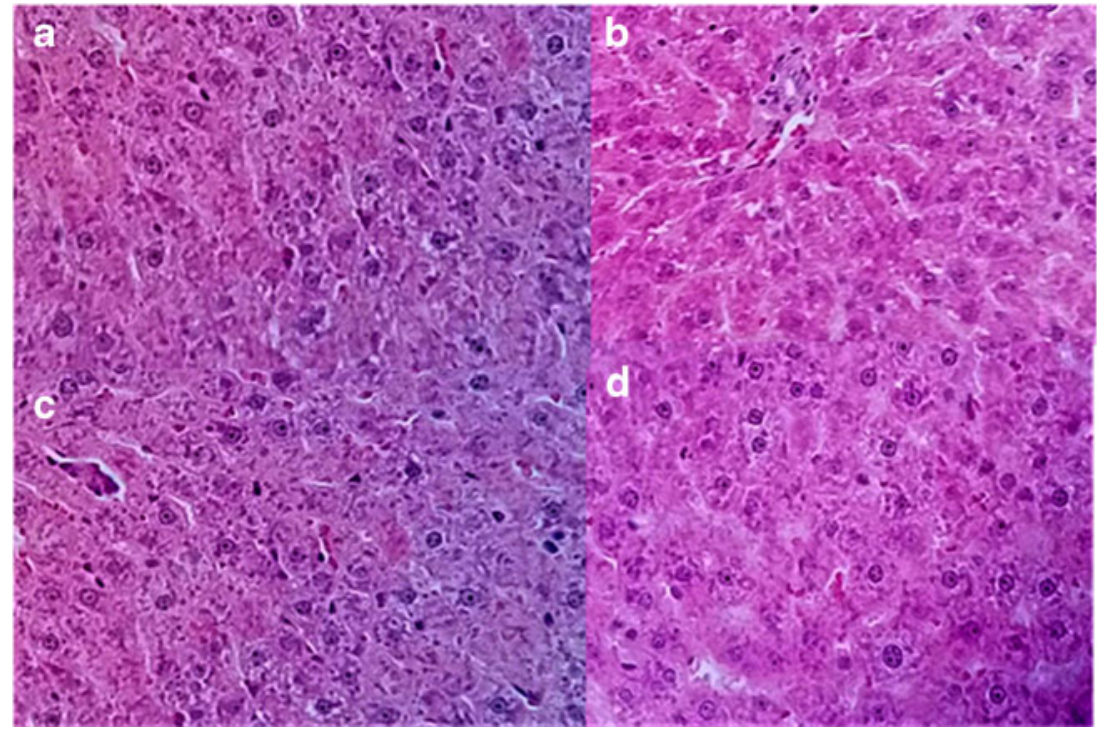

exposure). However, direct comparison with human health risks is not possible because crack cocaine is consumed by smoking.

The chemical analysis of crack cocaine was made initially by TLC, which is a classic technique in forensic science due to simplicity and low costs. It was applied to screen cocaine and other illicit drugs (Sabino et al. 2011). Nevertheless, TLC is limited in terms of accuracy. To enhance the analysis, ESI$\mathrm{MS}^{n}$ was used parallel with TLC, with low-energy collisioninduced dissociation (CID). This is a powerful analytical method for investigating illicit drugs, with excellent precision and reducing the risks of false positive and/or false negative (Guoa et al. 2009; Stojanovska et al. 2015). Our results confirmed the presence of cocaine as the main component in the crack cocaine sample and ensured that there were no other illicit compounds in the sample as already demonstrated by others (Bin Hu et al. 2010; Sundara and Rowell 2014).

Comet and micronucleus assays were used for evaluation of crack cocaine genotoxicity and mutagenicity, respectively, as a consistent method for detecting genetic damage. Our results demonstrated that crack cocaine was able to induce genetic damage in peripheral blood and liver cells as depicted by comet assay results, especially at higher doses used in this study. Our results are fully in line with previous studies that demonstrated that crack cocaine is able to induce genetic damage in blood cells in humans (de Freitas et al. 2014). Taken together, our results demonstrated that crack cocaine is genotoxic in peripheral blood and liver of rats after acute exposure. By comparison, previous studies conducted by our research group have demonstrated positive genotoxicity
Fig. 5 Photomicrographies from kidney of rats exposed to crack cocaine. a Control; b $4.5 \mathrm{mg} / \mathrm{kg}$; c $9 \mathrm{mg} / \mathrm{kg} ; \mathbf{d} 18 \mathrm{mg} / \mathrm{kg} ; \times 40$ magnification (H.E. stain)

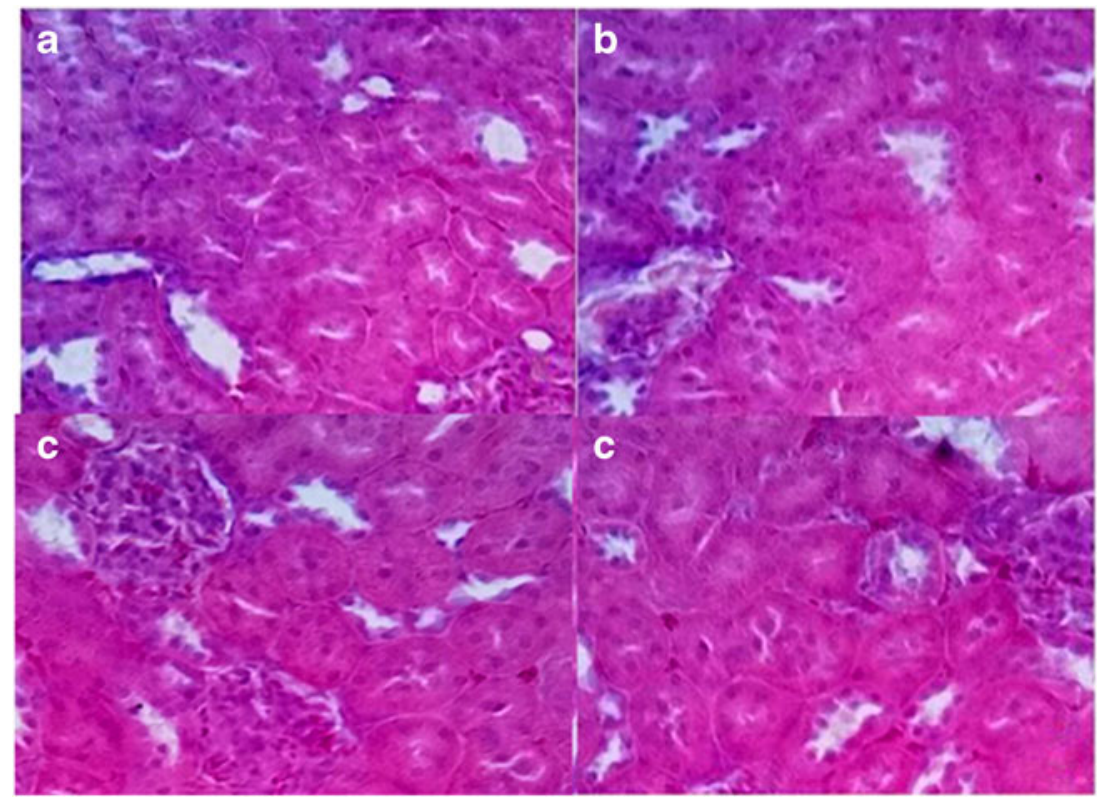


Fig. 6 Immunohistochemistry for 8-oHdG in liver following crack cocaine exposure. a Control; b $4.5 \mathrm{mg} / \mathrm{kg}$; $\mathbf{c} 9 \mathrm{mg} / \mathrm{kg}$; d $18 \mathrm{mg} / \mathrm{kg} ; \times 40$ magnification (H.E. stain)

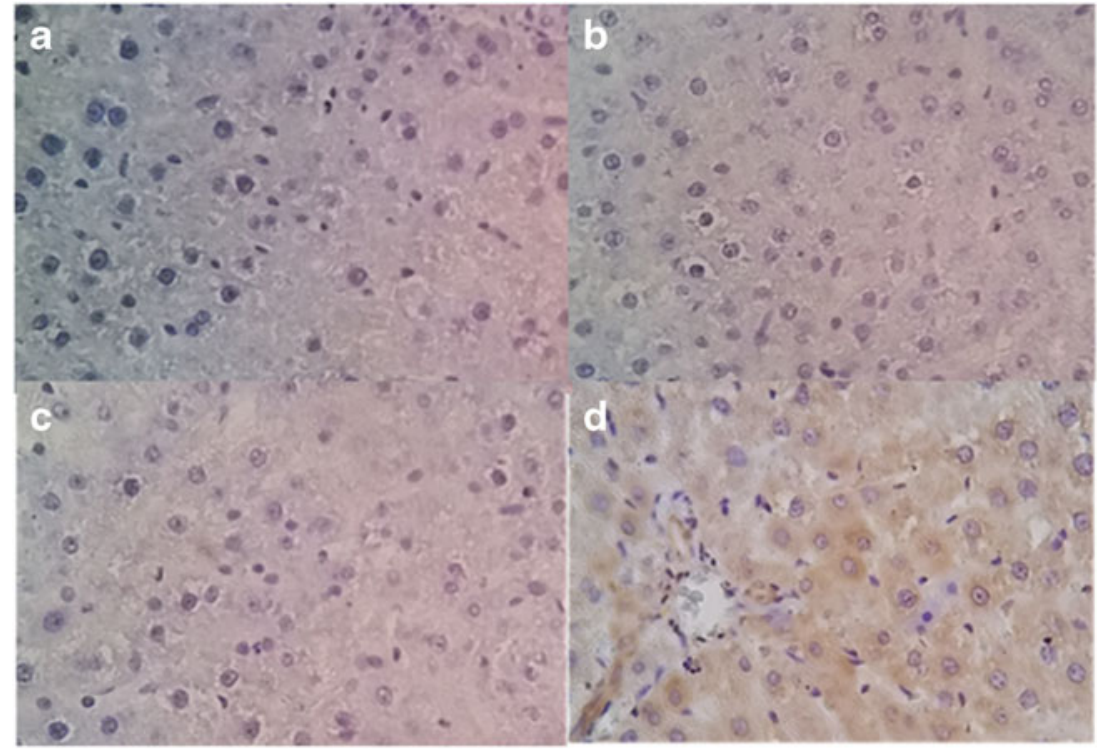

induced by cocaine in mice blood and liver cells after single exposure (Alvarenga et al. 2010, 2011).

Micronucleated cell indexes may reflect genetic damage (de Castro Marcondes et al. 2014). The detection of an elevated frequency of micronuclei in a given population indicates increased risk of cancer. Our results demonstrated that the micronucleus frequencies were significantly different between control and crack cocaine exposure in bone marrow cells. Liver cells did not show mutagenesis after acute crack cocaine exposure. By comparison, previous studies conducted by our research group have demonstrated that crack cocaine is able to induce micronucleus in buccal mucosa cells (Oliveira et al. 2014; Webber et al. 2015). This was also confirmed by others in human and other species (Almeida et al. 2012; Stefanidou et al. 2011). However, other studies have not demonstrated mutagenic effects induced by cocaine in bone marrow cells of mice (Salvadori et al. 1998). Taking into consideration that cocaine is the main component of crack cocaine based on a complex mixture of chemicals, it is probable that some substances other than cocaine are able to induce chromosome breakage or loss in cells. This requires further study.

Histopathological evaluation of liver and kidney tissues did not show significant differences among treatment groups. In fact, our hypothesis was that crack cocaine would not be able to induce morphological alterations in these organs because the experimental design was a short period of time ( $24 \mathrm{~h}$ only). To overcome this drawback, a new study has been planned to us to evaluate the microscopic findings in multiple organs of rats induced by crack cocaine using a sub-chronic assay. In mice, acute administration of cocaine induces dose-dependent necrosis of the liver associated with several biochemical alterations, including increased activities of serum transaminases
Fig. 7 Imunohistochemistry data for 8-oHdG in liver cells. Results are expressed as mean $+\mathrm{SD}$. ${ }^{*} p<0.05$ when compared with control group

\section{Mean of positive cells}

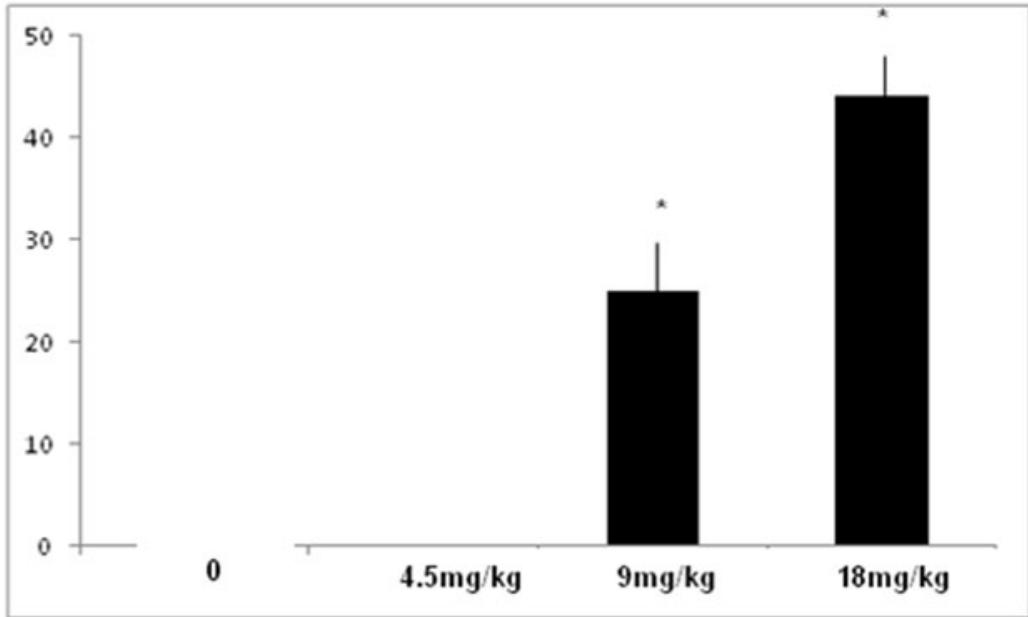

Groups 
(Mehanny and Abdel-Rahman 1991). In humans, the liver morphological and biochemical effects induced by cocaine are quite similar to those in mice (Silva et al. 1991). Oxidative stress, which seems to be one of the mechanisms associated with cocaine toxicity (Boelsterli et al. 1993), could play a role in the liver carcinogenesis process, similar to that exerted by peroxisome proliferators (Rao and Reddy 1991). The interaction of reactive oxygen species with the bases of the DNA strand, as guanine, leads to the formation of 8hydroxyguanine (8-OHGua) or its nucleoside form deoxyguanosine (8-hydroxy-2'-deoxyguanosine), leading to the generation of radical adducts and synthesis of $8-\mathrm{OHdG}$, one of the most important markers for measuring endogenous oxidative damage to DNA (Valavanidis et al. 2009). This conception was observed in the results obtained from 8-OHdG immunohistochemistry analysis, since crack cocaine exposure induced significant 8-OHdG immunoexpression elevation in liver cells when administrated at higher doses. We assume that oxidative stress plays an important role for genotoxicity induced by crack cocaine in liver cells.

In summary, our results demonstrate that crack cocaine is able to induce genomic damage in multiple organs of Wistar rats.

Acknowledgments This study was supported by the Conselho Nacional de Desenvolvimento Cientifico e Tecnologico (CNPq) and Coordenação de Aperfeiçoamento de Pessoal de NIvel Superior (CAPES).

\section{Compliance with ethical standards}

Conflict of interest None declared.

\section{References}

Almeida TC, Stefanon EB, Rech VC, Sagrillo MR, Bohrer PL (2012) Analysis of oral mucosa of users of crack through micronucleus technique. Clin Lab 58(11-12):1269-1275

Alvarenga TA, Andersen ML, Ribeiro DA, Araujo P, Hirotsu C, Costa JL, Battisti MC, Tufik S (2010) Single exposure to cocaine or ecstasy induces DNA damage in brain and other organs of mice. Addict Biol 15(1):96-99

Alvarenga TA, Ribeiro DA, Araujo P, Hirotsu C, Mazaro-Costa R, Costa JL, Battisti MC, Tufik S, Andersen ML (2011) Sleep loss and acute drug abuse can induce DNA damage in multiple organs of mice. Hum Exp Toxicol 30(9):1275-1281

Beliën JA, Copper MP, Braakhuis BJ, Snow GB, Baak JP (1995) Standardization of counting micronuclei: definition of a protocol to measure genotoxic damage in human exfoliated cells. Carcinogenesis 16(10):2395-2400

Bin Hu, Xuejiao P, Shuiping Y (2010) Fast quantitative detection of cocaine in beverages using nano extractive electrospray ionization tandem mass spectrometry. J Am Soc Mass Spectrom 21:290-293

Boelsterli UA, Wolf A, Goldlin C (1993) Oxygen free radical production mediated by cocaine and its ethanol-derived metabolite in rat hepatocytes. Hepatology 18:1154-1161

das Graças Alonso de Oliveira M, Dos Santos JN, Cury PR, da Silva VH, Oliveira NR, da Costa Padovani R, Tucci AM, Ribeiro DA (2014)
Cytogenetic biomonitoring of oral mucosa cells of crack cocaine users. Environ Sci Pollut Res Int 21(8):5760-5764

de Castro Marcondes JP, de Oliveira ML, Gontijo AM, de Camargo JL, Salvadori DM (2014) Genetic instability persists in non-neoplastic urothelial cells from patients with a history of urothelial cell carcinoma. PLoS One 9(1):e86162

de Freitas TA, Palazzo RP, de Andrade FM, Reichert CL, Pechansky F, Kessler F, de Farias CB, de Andrade GG, Leistner-Segal S, Maluf SW (2014) Genomic instability in human lymphocytes from male users of crack cocaine. Int J Environ Res Public Health 11(10): 10003-10015

de Moura CF, Ribeiro FA, de Jesus GP, da Silva VH, Oshima CT, Gollücke AP, Aguiar O Jr, Ribeiro DA (2014) Antimutagenic and antigenotoxic potential of grape juice concentrate in blood and liver of rats exposed to cadmium. Environ Sci Pollut Res Int 21(22): 13118-13126

Guoa Y-C, CaoaShu-Xia ZX-K, LiaoaXin-Cheng ZY-F (2009) ESI-MS ${ }^{n}$ studyonthefragmentation of protonatedcyclic-dipeptides. Spectroscopy 23:131-139

Halliwell B (2006) Oxidative stress and neurodegeneration: where are we now? J Neurochem 97:1634-1658

Hermida-Ameijeiras A, Mendez-Alvarez E, Sanchez-Iglesias S, SanmartinSuarez C, Soto-Otero R (2004) Autoxidation and MAOmediated metabolism of dopamine as a potential cause of oxidative stress: role of ferrous and ferric ions. Neurochem Int 45:103-116

Kendler KS, Myers J, Prescott CA (2007) Specificity of genetic and environmental risk factors for symptoms of cannabis, cocaine, alcohol, caffeine, and nicotine dependence. Arch Gen Psychiatry 64: $1313 \mathrm{e} 20$

Laranjeira R, Madruga CS, Pinsky I, Mitsuhiro S, Caetano R. II LENAD Levantamento Nacional de A' lcool e Drogas - O uso de maconha, cocal'na e crack no Brasil [Internet]. 2012 [cited 2013 Jan 24]. Available from: http:/ www.inpad.org.br/images/stories/LENAD/ lenad maconhacocaina.pdf.

Mehanny SZ, Abdel-Rahman MS (1991) Cocaine hepatotoxicity in mice: histologic and enzymatic studies. Toxicol Pathol 19:24-29

Minicucci EM, Ribeiro DA, de Camargo B, Costa MC, Ribeiro LR, Favero Salvadori DM (2008) DNA damage in lymphocytes and buccal mucosa cells of children with malignant tumours undergoing chemotherapy. Clin Exp Med 8(2):79-85

Moura HF, Benzano D, Pechansky F, Kessler FH (2014) Crack/cocaine users show more family problems than other substance users. Clinics (Sao Paulo) 69(7):497-499

Narvaez JCM, Magalhães PV, Fries GR, Colpo GD, Czepielewski LS, Vianna P, Chies JAB, Rosa AR, Diemen LV, Vieta E (2013) Peripheral toxicity in crack cocaine use disorders. Neurosci Lett 544:80-84

Oliveira LG, Nappo AS (2008) Characterization of the crack cocaine culture in the city of São Paulo: a controlled pattern of use. Rev Saude Publica 42(4):664-671

Rao SM, Reddy JK (1991) An overview of peroxisome proliferationinduced hepatocarcinogenesis. Environ Health Perspect 93:205-209

Riezzo I, Fiore C, de Carlo C, Pascale N, Neri M, Turillazzi E, Fineschi V (2012) Side effects of cocaine abuse: multiorgan toxicity and pathological consequences current. Med Chem 19:5624-5646

Sabino BD, Romão W, Sodré ML (2011) Analysisof cocaine and crack cocaine via thin layer chromatography coupled to easy ambient sonic-spray ionization mass spectrometry. Am J Analyt Chem 2: $658-664$

Salvadori DM, Barbisan LF, Bazo AP, de Santana EQ, Denadai R, de Oliveira SV, Ribeiro LR, de Camargo JL (1998) Cocaine mutagenicity and hepatocarcinogenicity evaluations in rodents. Teratog Carcinog Mutagen 18(4):199-208

Salzwedel AP, Grewen KM, Vachet C, Gerig G, Lin W, Gao W (2015) Prenatal drug exposure affects neonatal brain functional connectivity. J Neurosci 35(14):5860-5869 
Silva MO, Roth D, Reddy KR, Fernandez JA, Albores-Saavedra J, Schiff ER (1991) Hepatic dysfunction accompanying cocaine intoxication. J Hepatol 12:312-315

Stefanidou ME, Hatzi VI, Terzoudi GI, Loutsidou AC, Maravelias CP (2011) Effect of cocaine and crack on the ploidy status of Tetrahymena pyriformis: a study using DNA image analysis. Cytotechnology 63(1):35-40

Stojanovska N, Tahtouh M, Kelly T, Beavis A, Fu S (2015) Qualitative analysis of seized cocaine samples using desorption electrospray ionization-mass spectrometry (DESI-MS). Drug Test Analyst 5: 393-400

Sundara L, Rowel F (2014) Detection of drugs in lifted cyanoacrylate developed latent fingermarks using two laser desorption/ionisation mass spectrometric methods. Analyst. 633-642.

Tice RR, Agurell E, Anderson D, Burlinson B, Hartmann A, Kobayashi H, Miyamae Y, Rojas E, Ryu JC, Sasaki YF (2000) Single cell gel/ comet assay: guidelines for in vitro and in vivo genetic toxicology testing. Envirom Mol Mutag 35:206-221
Valavanidis A, Vlachogianni T, Fiotakis C (2009) 8-hydroxy-2'deoxyguanosine (8-OHdG): a critical biomarker of oxidative stress and carcinogenesis. J Environ Sci Health C Environ Carcinog Ecotoxicol Rev 27(2):120-139

Van Berkel GJ, Ford MJ, Deibel MA (2005) Thin-layer chromatography and mass spectrometry coupled using desorption electrospray ionization. Anal Chem 77(5):1207-1215

Vaughn MG, Fu Q, Perron BE, Bohnert AS, Howard MO (2010) Is crack cocaine use associated with greater violence than powdered cocaine use? Results from a national sample. Am J Drug Alcohol Abuse 36(4):181-186

Webber LP, Pellicioli A, Magnusson AS, Danilevicz CK, Bueno CC, Filho MS, Rados PV, Carrard VC. Nuclear changes in oral mucosa of alcoholics and crack cocaine users. Hum Exp Toxicol. 2015, in press.

Zaparte A, Viola TW, Grassi-Oliveira R, da Silva MM, Moreira JC, Bauer ME (2015) Early abstinence of crack-cocaine is effective to attenuate oxidative stress and to improve antioxidant defences. Psychopharmacology (Berl) 232(8):1405-1413 